\title{
Flower sprayings with plant growth regulators and fungicides to improve the yield of glasshouse eggplants (Solanum melongena L.)
}

\author{
W. van Ravestijn \\ Glasshouse Crops Research Station, P.O. Box 8, NL 2670 AA Naaldwijk, Nether- \\ lands
}

Received 1 February 1988; accepted 14 April 1988

Key words: Solanum melongena, plant growth regulators, fungicides, fruit development

\begin{abstract}
Experiments were carried out to study possibilities of increasing yield of glasshouse eggplants (Solanum melongena L.) by improved fruit growth and reduced incidence of fruit rot. Of the tested plant growth regulators (PGRs) and fungicides, spraying a mixture of $20 \mathrm{mg} \mathrm{l}^{-1} 4$-CPA and $500 \mathrm{mg} \mathrm{l}^{-1}$ iprodione on flower buds (7 days or less before anthesis) or flowers (at anthesis to 4 days later) at weekly intervals gave the best results. These sprayings can be applied both in early (planted in January) and in late crops (planted in June-July).

Spraying in or on the flowers did not affect yield. Weekly sprayings have to be continued during the whole flowering period. Both cultivars used, Adona and Claresse, reacted positively.
\end{abstract}

\section{Introduction}

In winter under limited light conditions (ca $100-350 \mathrm{~J} \mathrm{~cm}^{-2} \mathrm{day}^{-1}$ ) growth of ovaries of eggplant is poor. Moreover many young fruits are lost because of fruit rot (Botrytis cinerea). Literature data (Lipari et al., 1981; Martinoni et al., 1981; Nothmann et al., 1983; Olympios, 1976; Saito, 1975) indicate that PGRs may enhance fruit growth by improving the sink effect. Therefore the use of PGRs was studied.

Fruit rot is promoted by the corolla remaining stuck between the fruit and the calyx, the so-called 'sticking' of the corolla. This may occur spontaneously but the use of auxins seems to increase this phenomenon (Fujime et al., 1981; Musard, 1985).

Many authors (Cartia et al., 1982; Costache et al., 1982; Morgan, 1979; Musard, 1985) describe experiments to improve fruit growth with PGRs or to control fruit rot with fungicides. The present paper describes experiments in which improved fruit growth by PGRs was combined with control of fruit rot with fungicides. This 
was done by spraying flowers and flower buds with a mixture of PGR and fungicide, during winter and during summer (light conditions $1000-2000 \mathrm{~J} \mathrm{~cm}^{-2} \mathrm{day}^{-1}$ ), to examine the possibility of improving the yield in both seasons.

\section{Materials and methods}

All experiments were carried out between 1976 and 1982. The eggplants were grown under winter (100-350 $\left.\mathrm{J} \mathrm{cm}^{-2} \mathrm{day}^{-1}\right)$ and summer (1000-2000 J cm $\mathrm{day}^{-1}$ ) conditions. The temperature regime was $19^{\circ} \mathrm{C}$ at night and $20^{\circ} \mathrm{C}$ by day.

In Experiment I, different PGRs were tested. The following treatments were compared: (1) control, no spraying; (2) $50 \mathrm{mg} \mathrm{l}^{-1}$ 2-naphthoxyacetic acid (NOXA) and $2.5 \mathrm{mg} \mathrm{l}^{-1} \mathrm{Na}$-salt of 2.4-dichlorophenoxyacetic acid (2,4-D); (3) $20 \mathrm{mg} \mathrm{l}^{-1} 4$ chlorophenoxyacetic acid (4-CPA); (4) $100 \mathrm{mg} \mathrm{l}^{-1}$ gibberellas $4+7\left(\mathrm{GA}_{4+7}\right)$. From 22 April to 8 July the flowers were sprayed once a week. Experiment I was conducted in twelvefold in plots of 6 plants. The cultivar used was Claresse, planted 4 January.

In Experiments II and III, the effect of different fungicides was studied in combination with NOXA and 4-CPA, respectively. In Experiment II the following treatments were compared: (1) control, no spraying; (2) $500 \mathrm{mg} \mathrm{l}^{-1} \mathrm{NOXA}+2.5 \mathrm{mg} \mathrm{l}^{-1}$ Na-salt of $2.4 \mathrm{D}$; (3) $500 \mathrm{mg} \mathrm{l}^{-1}$ benomyl (Benlate with $50 \%$ benomyl); (4) $50 \mathrm{mg} \mathrm{l}^{-1}$ $\mathrm{NOXA}+2.5 \mathrm{mg} \mathrm{l}^{-1} \mathrm{Na}$-salt of $2,4-\mathrm{D}+500 \mathrm{mg} \mathrm{l}^{-1}$ benomyl. From 17 August to 26 October the flowers in bloom were sprayed once a week. Experiment II was conducted in twelvefold in plots of 7 plants of cv. Claresse, planted $5 \mathrm{July}$.

Experiment III consisted of the following treatments: (1) control, no spraying; (2) $20 \mathrm{mg} \mathrm{l}^{-1} 4$-CPA; (3) $500 \mathrm{mg} \mathrm{l}^{-1}$ iprodione (trade mark Rovral with $50 \%$ iprodione); (4) $20 \mathrm{mg} \mathrm{l}^{-1} 4$-CPA $+500 \mathrm{mg} \mathrm{l}^{-1}$ iprodione. The flowers were sprayed once a week from 2 February to 20 June. The experiment was conducted in fourfold in plots of 6 plants of cv. Claresse, planted 3 January.

In Experiment IV, spraying of 4-CPA + iprodione in relation to flowering stage was studied. The following treatments were compared: (1) control, no spraying; (2) spraying before or at anthesis; (3) spraying at anthesis or later. 'Before anthesis' means spraying flower buds about 1-2 weeks before anthesis. 'After anthesis' means that only open flowers were sprayed within a week. In order to obtain more detailed information on dates of flowering and spraying, recordings of both were made. The spraying solution consisted of $20 \mathrm{mg} \mathrm{l}^{-1} 4$-CPA $+500 \mathrm{mg} \mathrm{l}^{-1}$ iprodione. The spraying frequency was once a week in the period from 8 February to 31 May. The experiment was conducted in duplicate in plots of 6 plants of cvs Adona and Claresse, planted 12 January.

In Experiment $V$, the effect of the method of spraying was studied. In the above experiments spraying was performed in the flowers so that stigma, style, ovary, stamina and corolla were wetted. This method was compared to spraying on the flowers, i.e. wetting the pedicle, the calyx and the corolla. The treatments compared were: (1) control, no spraying; (2) spraying in the flowers; (3) spraying on the flowers. The spraying solution consisted of $20 \mathrm{mg} \mathrm{l}^{-1} 4$-CPA and $500 \mathrm{mg} \mathrm{l}^{-1}$ iprodione. The flowers were sprayed once a week from 13 February to 29 July. Experiment V 
was conducted in tenfold in plots of 10 plants of cv. Adona, planted 5 January.

In Experiments VI and VII, the effect of the spraying period was studied. In Experiment VI the following treatments were compared: (1) control, no spraying; (2) spraying from 13 February to 17 April (10 times); (3) spraying from 13 February to 26 June (20 times). The spraying solution consisted of $20 \mathrm{mg} \mathrm{l}^{-1} 4$-CPA and $500 \mathrm{mg}$ $\mathrm{I}^{-1}$ iprodione. The flowers were sprayed once a week. Experiment VI was conducted in sixfold in plots of 6 plants of cv. Claresse, planted 5 January.

In Experiment VII, the same treatments were compared in a late crop: (1) control, no spraying; (2) spraying from 1 September to 20 October ( 8 times); (3) spraying from 27 July to 20 October ( 13 times). The composition of the spraying solution was the same as in Experiment VI. The flowers were sprayed once a week. Experiment VII was conducted in quadruplicate with plots of 9 plants (cv. Adona, planting date 23 June).

In Experiments VIII and IX, the effect of the spraying frequency was studied. Because under favourable conditions (summer period) the flowering period is shorter than in early spring and late autumn, the spraying frequency should be adapted. In order to investigate the frequency of spraying under both conditions, two experiments were conducted.

In Experiment VIII, four treatments were compared: (1) control, no spraying; (2) spraying the flowers twice a week; (3) spraying the flowers three times per fortnight; (4) spraying the flowering flowers once a week. The spraying period was from 11 February to 26 June. The spraying solution consisted of $20 \mathrm{mg} \mathrm{l}^{-1} 4$-CPA + $500 \mathrm{mg} \mathrm{l}^{-1}$ iprodione. Experiment VIII was conducted in sixfold in plots of 10 plants (cv. Adona, planting date 15 January).

In Experiment IX, the same spraying solution was used as in Experiment VIII. The following treatments were compared: (1) control, no spraying; (2) spraying the flowers twice a week; (3) spraying the flowers once a week; (4) spraying the flowers twice in 3 weeks. The spraying period was from 24 July to 25 October. The experiment was conducted in quadruplicate in plots of 9 plants $(\mathrm{cv}$. Adona, planted 1 July).

\section{Results}

The application of PGRs resulted in an earlier and higher yield compared to the control treatment (Experiment 1, Table 1). The auxins 4-CPA or a mixture of 2 NOXA + Na-salt of 2,4-D promoted the development of heavier fruits with a darker colour. $\mathrm{GA}_{4+7}$ caused yield improvement by increasing the number of fruits. 4CPA reduced the maturation period from 32.5 days for the control treatment to 31.1 days $(\operatorname{LSD} 1 \%=0.3)$.

Adding benomyl to the spraying solution improved neither fruit rot control nor the yield in comparison to PGRs exclusively (Experiment II, Table 2). Iprodione effectively controlled fruit rot, whereas 4-CPA enhanced the incidence of fruit rot (Experiment III, Table 3). 4-CPA shortened the maturation period of fruits. The combined spraying was effective both with regard to fruit development and the control of fruit rot. 
Table 1. Effect of some growth regulators on the yield per plant in the period 24 March - 17 May (Experiment I).

\begin{tabular}{llll}
\hline Treatment & \multicolumn{3}{l}{ Yield and average fruit weight } \\
\cline { 2 - 3 } & $\begin{array}{l}\text { number } \\
\text { (fruits/plant) }\end{array}$ & $\begin{array}{l}\text { weight } \\
\text { (kg/plant) }\end{array}$ & $\begin{array}{l}\text { fruit weight } \\
\text { (g/fruit) }\end{array}$ \\
Control, untreated & 13.8 & 3.21 & 237 \\
NOXA + 2.4-D & 13.8 & 3.83 & 277 \\
4-CPA & 13.9 & 3.80 & 273 \\
GA & 14.9 & 3.53 & 237 \\
& & & \\
LSD $(5 \%)$ & 0.5 & 0.28 & 23 \\
LSD $(1 \%)$ & 0.7 & 0.42 & 34 \\
\hline
\end{tabular}

Table 2. Effect of benomyl and NOXA + 2,4-D on the yield per plant in the period 30 August - 22 November (Experiment II).

\begin{tabular}{lcl}
\hline Treatment & $\begin{array}{l}\text { Number } \\
\text { (fruits/plant) }\end{array}$ & $\begin{array}{l}\text { Weight } \\
\text { (kg/plant) }\end{array}$ \\
Control, untreated & 9.3 & 2.24 \\
NOXA + 2.4-D & 12.2 & 3.08 \\
Benomyl & 9.4 & 2.25 \\
NOXA + 2.4-D + benomyl & 12.3 & 3.13 \\
& & \\
LSD $(1 \%)$ & 1.2 & 0.56 \\
LSD $(5 \%)$ & 1.7 & 0.75 \\
\hline
\end{tabular}

Table 3. Effect of iprodione and 4-CPA on the early growth of fruits and on the incidence of fruit rot (Experiment III).

\begin{tabular}{lll}
\hline Treatment & $\begin{array}{l}\text { Number of immature } \\
\text { fruits per plant } \\
\text { on 15 March }\end{array}$ & $\begin{array}{l}\text { Number of rotten } \\
\text { fruits from } \\
\text { 29 March to 17 May }\end{array}$ \\
Control, untreated & 0.29 & 0.10 \\
iprodione & 0.25 & 0.02 \\
4-CPA & 1.25 & 0.20 \\
4-CPA + iprodione & 1.39 & 0.09 \\
LSD $(5 \%)$ & 0.18 & 0.03 \\
LSD $(1 \%)$ & 0.26 & 0.04 \\
\hline
\end{tabular}

In Experiment IV, 'early' spraying (before or at anthesis) occurred on average 4 days before anthesis. About $90 \%$ of these fruits originated from flower buds and flowers sprayed within 7 days before anthesis. About $95 \%$ of the flowers of the 'late' treatment were sprayed within 4 days after anthesis with an overall average of 2 days after anthesis. The moment of spraying did not affect the yield significantly. 
Table 4. Effect of spraying method on the yield and number of rotten fruits per plant in the period 3 April - 7 October (Experiment V).

\begin{tabular}{lcll}
\hline Treatment & Number & $\begin{array}{l}\text { Weight } \\
(\mathrm{kg})\end{array}$ & $\begin{array}{l}\text { Number of } \\
\text { rotten fruits }\end{array}$ \\
Control, untreated & 27.8 & 7.80 & 0.68 \\
Spraying in the flowers & 31.3 & 8.58 & 0.22 \\
Spraying on the flowers & 30.4 & 8.54 & 0.45 \\
& & & \\
LSD $(5 \%)$ & 1.6 & 0.50 & 0.25 \\
LSD $(1 \%)$ & 2.2 & 0.68 & 0.34 \\
\hline
\end{tabular}

Table 5. Effect of spraying frequency in an early and a late crop on total yield per plant (in $\mathrm{kg}$ ). Experiment VIII: planting date 15 January, harvesting period from 7 April to 28 July. Experiment IX: planting date 1 July, harvesting period from 1 September to 17 November.

\begin{tabular}{lll}
\hline Treatment & \multicolumn{2}{l}{ Total yield $(\mathrm{kg})$} \\
\cline { 2 - 3 } & Exp. VIII & Exp. IX \\
No spraying & 6.85 & 1.89 \\
Spraying twice per 3 weeks & - & 2.41 \\
Spraying once a week & 7.54 & 2.66 \\
Spraying 3 times per fortnight & 7.79 & 2.55 \\
Spraying twice a week & 7.71 & - \\
& & \\
LSD $(5 \%)$ & 0.61 & 0.15 \\
LSD $(1 \%)$ & 0.76 & 0.20 \\
\hline
\end{tabular}

On 28 June the untreated plants produced $3.23 \mathrm{~kg} \mathrm{plant}^{-1}$. The yield of the 'early' and the 'late' sprayings was 5.02 and $4.96 \mathrm{~kg} \mathrm{plant}^{-1}$, respectively (LSD $5 \%=0.47$; LSD $1 \%=0.73$ ).

The method of spraying (Experiment $\mathrm{V}$, Table 4) did not affect the yield in number nor in weight of the fruits. Both spraying methods increased the yield significantly in comparison with untreated. Spraying in flowers resulted in $68 \%$ less fruits with rot than in the control treatment $(P<0.01)$.

Shortening the spraying period (Experiments VI and VII) resulted in a significant yield reduction. In Experiment VI yield stagnated ca 6 weeks after the last spraying (Fig. 1A). When in the autumn crop (Experiment VII) no spraying was carried out, the yield remained behind that of the sprayed plants. About 6 weeks after the first spraying the yield increased significantly in comparison with no spraying (Fig. 1B). The yield deficit in comparison to the long spraying treatment was, however, not equalized.

In the Experiments VIII and IX, spraying more than once a week did not result in yield increase, compared to spraying once a week. Spraying less frequently than once a week gave a significant reduction in yield. Still, yield of less frequently sprayed plants was higher than of the unsprayed ones (Table 5). 


\section{Yield $\mathrm{kg} / \mathrm{plant}$ )}

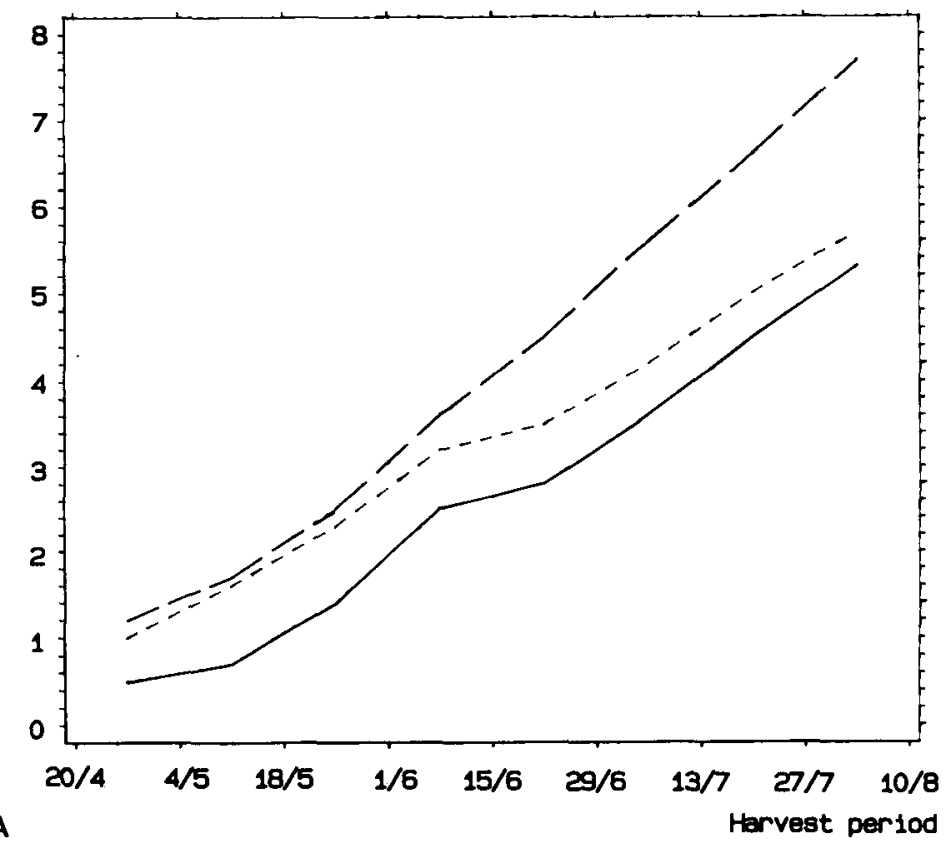

\section{Yield (kg/plant)}

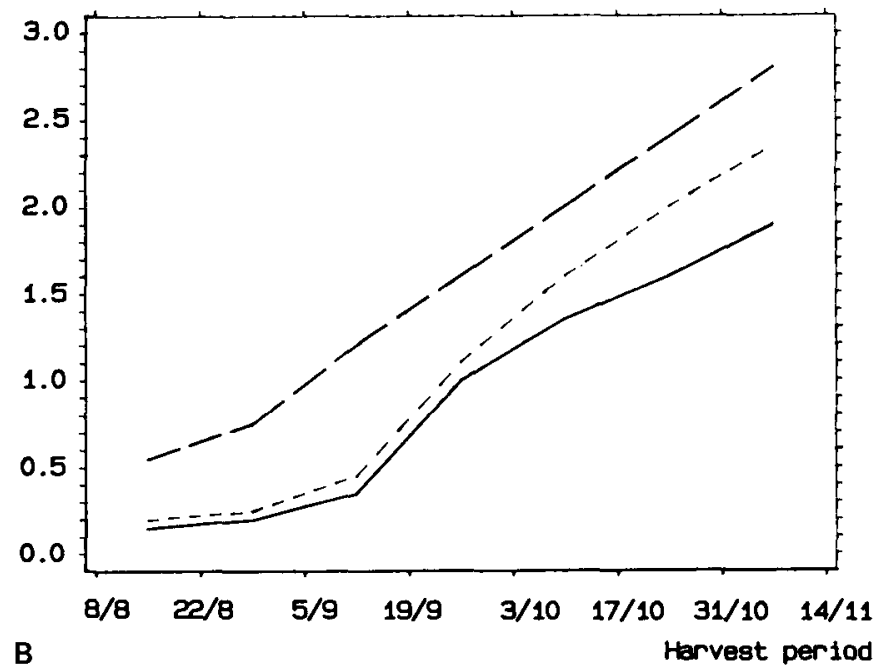

Fig. 1. Effect of spraying period on the summed yield in kg per plant. (A) Early crop (Exp. VI): - no spraying, - - spraying 13/2-17/4. - - spraying 13/2-26/6. (B) Autumn crop (Exp. VII): - no spraying, - - spraying $1 / 9-20 / 10,-\ldots$ spraying $27 / 7-20 / 10$. 


\section{Discussion}

Compared to the control treatment, auxins gave heavier fruits with a darker fruit colour. This agrees with the results of Martinoni et al. (1981). This is possibly caused by an increased sink effect, as reported by Nothmann (1975). Applying $\mathrm{GA}_{4+7}$ resulted in a higher number of fruits than the control treatment, possibly caused by increased parthenocarpy (Nothmann et al., 1975). Benomyl was ineffective in controlling fruit rot, iprodione protected the fruits against rot. This is in contradiction with the results of Cartia \& Pacetto (1982). They found the best results after spraying vinchlozolin and procymidone followed by iprodione, dichlozolinate and benomyl. The test crop (Capsicum) and the experimental conditions, however, were different. Combined sprayings of 4-CPA and iprodione gave the best results in stimulating the growth of the fruits and in controlling fruit rot in our experiments.

About $90-95 \%$ of the ovaries are sensitive to the 4-CPA + iprodione sprays from 7 days before anthesis to 4 days after anthesis. This partially agrees with the findings of Nothmann et al. (1983). They only studied sprayings after anthesis and found that the newly opened flowers were most sensitive to the PGR spraying.

The effect of combined 4-CPA/fungicide sprayings displays itself ca 6 weeks after ending and start of the spraying in an early and in an autumn crop, respectively (Figs. 1A and 1B). Since the maturation period of fruit is about 5 weeks, this proves that the 4-CPA/fungicide mixture is effective exclusively on the treated flowers, so spraying for the duration of the whole flowering period resulted in the highest yield.

Since higher spraying frequencies imply more labour and do not improve yield, spraying once a week is the most effective strategy for early as well as for autumn crops. Lower spraying frequencies decreased the yield compared to spraying once a week.

\section{References}

Cartia, G. \& M. Pacetto, 1982. Control trial against grey mould of Capsicum in protected culture. Tecnica Agricola ltaly 34: 263-270.

Costache, M., A. Tomescu \& N. Dragomin, 1982. New fungicides for the control of tomato pathogens. Productia Vegetala Horticultura 31: 16-21.

Fujime, Y.. T. Horose \& K. Hori, 1979. Effects of ethephon on corolla abscission by eggplant fruits Studies from the Institute of Horticulture, Kyoto University 9: 71-77.

Lipari. V.. 1981. Green pruning and auxin treatments of eggplants. Colture Protetti 10: 39-44.

Martinoni, A., V. Canvescini, A. Granges, 1981. Fruit set induction and yield increase in eggplant by use of 4-chlorophenoxyacetic acid (4-CPA). Revue Suisse de Viticulture, Arboriculture et Horticulture 13: $109-112$.

Morgan, W. M.. 1979. Control of Botrytis cinerea in glasshouse tomato by high volume sprays. Annals of Applied Biology $91: 337-344$.

Musard, M. . 1985. Eggplants in the greenhouse. Revue Horticole 240: 43-46.

Nothmann, J. \& D. Koller, 1975. Effect of growth regulators in fruit and seed development in eggplant (Solanum melongena L.). Journal of Horticultural Science 50: 23-27.

Nothmann, J.. S. Rylski \& M. Spigelman, 1983. Interactions between floral morphology, position in cluster and 2,4-D treatment in three eggplant cultivars. Scientia Horticulturae 20: 35-40.

Olympios, C. M. . 1976. Effects of growth regulators on fruit set and fruit development of the eggplant (Solanum melongena L.). Horticultural Research 16: 65-70. 


\section{W. VAN RAVESTIJN}

Saito, T., 1975. Studies on flowering and fruiting in eggplants. VI. Effects of plant growth regulating substances on the vegetative growth and flower formation. Journal of the Yamagata Agriculture and Forestry Society 32: 54-70. 